\title{
Histological survey of four species of cultivated molluscs in Chile susceptible to OIE notifiable diseases
}

\author{
Catastro histológico de cuatro especies de moluscos cultivados en Chile susceptibles a \\ enfermedades de declaración obligatoria a la OIE \\ Mariel Campalans ${ }^{1,2}$ and Karin B. Lohrmann ${ }^{2}$ \\ ${ }^{1}$ Escuela de Ciencias del Mar, Pontificia Universidad Católica de Valparaíso, Av. Altamirano 1480, Valparaíso, Chile \\ ${ }^{2}$ Facultad de Ciencias del Mar, Universidad Católica del Norte, Larrondo 1281, Coquimbo, Chile \\ klohrman@ucn.cl
}

\begin{abstract}
Resumen.- Se examinaron moluscos cultivados en Chile para detectar la presencia de enfermedades de declaración obligada a la OIE (Office International des Epizooties: Organización Mundial de Sanidad Animal). Se tomaron muestras de tejidos, en invierno y en verano, de las especies susceptibles que se cultivan en el país, los abalones Haliotis discus hannai y H. rufescens, y las ostras Crassostrea gigas y Ostrea chilensis. Se realizaron cortes histológicos de todos los moluscos obtenidos y para el caso de ostra chilena, se procesó además tejido para observación en microscopio electrónico de transmisión (MET) para describir al protozoo tipo Bonamia presente en los hemocitos de algunas ostras. El único patógeno de declaración obligada a la OIE que se encontró fue Xenohaliotis californiensis en $H$. rufescens, bacteria que se encontró formando inclusiones intracelulares en epitelios digestivos, principalmente post-esófago y glándula digestiva. La descripción ultraestructural del protozoo tipo Bonamia sp. indica que se parece en algunos aspectos y difiere en otros, de las especies $B$. ostreae y B. exitiosa, pertenecientes al listado de enfermedades de moluscos de declaración obligada de la OIE.
\end{abstract}

Palabras clave: Enfermedades de moluscos, Bonamia sp., OTR en abalones, Xenohaliotis californiensis

\section{Introduction}

Mollusc culture is an important economic and social activity in Chile, being practised both on native and exotic species. The main native cultured species are scallops (Argopecten purpuratus Lamarck, 1819), mussels (Mytilus chilensis (Hupé, 1854), Choromytilus chorus (Molina, 1782), Aulacomya atra (Molina, 1782)) and the flat oyster (Ostrea chilensis Philippi, 1845). Farmed exotic species are red abalone (Haliotis rufescens Swainson, 1822), Pacific abalone (Haliotis discus hannai Ino, 1953), and the Pacific oyster (Crassostrea gigas Thunberg, 1795).

The OIE (Office International des Epizooties: the World Organization for Animal Health) listed diseases of molluscs are: Infection with Bonamia ostreae, $B$.

\begin{abstract}
Shellfish cultured in Chile were analyzed to detect the presence of diseases notifiable to OIE (Office International des Epizooties: the World Organization for Animal Health). Tissue samples of the susceptible species, the abalones Haliotis discus hannai, H. rufescens, and oysters Crassostrea gigas, and Ostrea chilensis cultured in Chile were collected in winter and summer. Histological sections were performed of all species; furthermore, tissue from the Chilean oyster $(O$. chilensis) was processed for transmission electron microscopy (TEM) to describe the Bonamia-like protozoan detected in the haemocytes of some oysters. The only pathogen from the list of notifiable diseases of the OIE was Xenohaliotis californiensis in $H$. rufescens. This bacterium formed intracellular inclusions in digestive epithelia, mainly in the post-esophagus and digestive gland. The ultrastructural description of the Bonamia -like protozoan shows it is similar in some features and different in others from the species B. ostreae. and B. exitiosa included in the list of notifiable diseases of the OIE.
\end{abstract}

Key words: Mollusc diseases, Bonamia sp., RLOs in abalones, Xenohaliotis californiensis

exitiosa, Marteilia refringens, Perkinsus marinus, $P$. olseni, Xenohaliotis californiensis and abalone viral mortality (OIE 2008'). The cultivated molluscs in Chile susceptible to these pathogens are the oysters $O$. chilensis and $C$. gigas, as well as the abalones $H$. discus hannai and $H$. rufescens. Chile is an OIE member and as such, is obliged to notify the occurrence of any of the listed diseases.

Considering the increasing trade of molluscs, and the international necessity for surveillance and zoning, the fisheries governmental agency (Subsecretaría de Pesca) developed two lists of high risk diseases for molluscs in

\footnotetext{
${ }^{1}$ OIE. 2008. Aquatic Animal Health Code. Chapter 1.2.3. Diseases listed by the OIE. [on-line] <http://www.oie.int/eng/ normes/fcode/en_chapitre_1.2.3.htm>
} 
Chile, which were released in January 2002. These lists are assessed each year by a group of national experts, and modified, if necessary. List 1 includes all OIE listed diseases, excluding those known to be present in Chile. On the other hand, list 2 includes the OIE listed diseases that are present in Chile, and/or other infections considered of high risk in the country.

Information on protistan or prokaryotic parasites is scarce, and only some of it has been published. Haemic neoplasia is a pathological condition of still unknown origin, described from Ostrea chilensis (Mix \& Breese 1980, Rojas et al. 1999) and Mytilus chilensis (Campalans et al. 1998); a Bonamia-like parasite was described from O. chilensis (Kern 19932, Campalans et al. 2000). Rickettsiales-like organisms (RLOs) have been reported from scallops (Argopecten purpuratus), with no evidence of damage to the host (Lohrmann et al. 2002).

The two areas concentrating $98 \%$ of the mollusc production were studied, in an attempt to get a better understanding of the current health status of Chilean cultivated molluscs.

\section{Material and methods}

Four mollusc species were studied: Haliotis rufescens (Swainson, 1822), H. discus hannai (Ino, 1953), Crassostrea gigas (Thunberg, 1795) and Ostrea chilensis (Philippi, 1845). Mollusc cultivation in Chile is carried out in two zones, one in the northern part of the country, between latitudes $27^{\circ}$ and $32^{\circ} \mathrm{S}$, and the other one in the south, between latitudes $41^{\circ}$ and $42^{\circ} \mathrm{S}$ (Fig. 1). The number of individuals of each species sampled from these sites for each season is shown in Table 1.

Two samplings were performed for all species: springsummer 2003 (December-January) and fall-winter (AprilAugust) 2004. The intended sample size was 60 specimens by location; however, this was not always possible. Therefore in each case a minimum of 20 individuals from each farm in the same location was sampled. An additional sampling of $O$. chilensis was performed in August 2004 (winter).

Table 1

Sampling locations and number of specimens collected from each species in summer, autumn and winter

Localidades de muestreo y número de especímenes recolectados de cada especie en verano, otoño e invierno

\begin{tabular}{llcccc}
\hline \multicolumn{1}{c}{ Location } & \multicolumn{1}{c}{ Species } & $\begin{array}{c}\text { Summer } \\
\mathrm{N}^{\circ} \text { sampled }\end{array}$ & $\begin{array}{c}\text { Autumn } \\
\mathrm{N}^{\circ} \text { sampled }\end{array}$ & $\begin{array}{c}\text { Winter } \\
\mathrm{N}^{\circ} \text { sampled }\end{array}$ & $\begin{array}{c}\text { Total } \\
\text { sampled }\end{array}$ \\
\hline $\begin{array}{l}\text { Northern zone } \\
\text { Caldera }\end{array}$ & H. rufescens & 62 & & 59 & 121 \\
& H. discus hannai & 60 & & 60 & 120 \\
Guanaqueros & H. discus hannai & 60 & & 60 & 120 \\
Tongoy & C. gigas & 57 & & 63 & 120 \\
Los Molles & H. rufescens & 49 & & 60 & 109 \\
Southern zone & O. chilensis & 60 & 60 & 60 & 180 \\
Calbuco & C. gigas & 86 & & 34 & 120 \\
Ancud & O. chilensis & 60 & 60 & 70 & 190 \\
Dalcahue & C. gigas & 87 & & 50 & 137 \\
& H. rufescens & 38 & & 50 & 88 \\
Chonchi & H. rufescens & 112 & & 70 & 182 \\
\hline
\end{tabular}

\footnotetext{
${ }^{2}$ Kern FG. 1993. Shellfish health inspections of Chilean and Australian oysters. Journal of Shellfish Research 12: 366 [Abstract]
} 


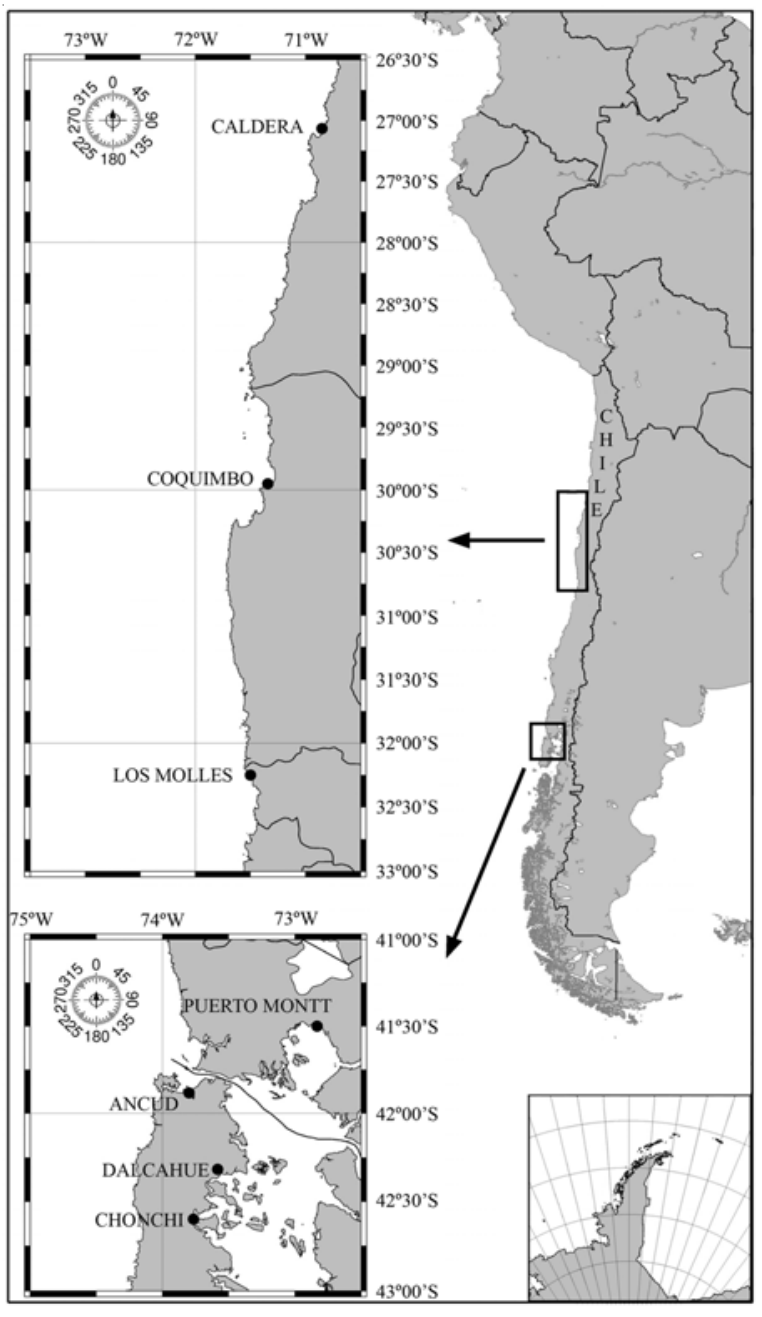

Figure 1

Location of the sampling zones

Ubicación de las zonas de muestreo

\section{Histology}

Soft tissues were removed from the shell and sectioned, including digestive gland, gills, mantle and kidney, placed in tissue embedding cassettes, and fixed in Davidson's fluid for 24 hours (Shaw \& Battle 1957). They were then transferred to $70 \%$ ethanol, and further processed for histology. Five $\mu \mathrm{m}$ thick sections were stained with Harris haematoxylin and alcoholic eosin, and carefully analyzed for any putative pathogens. Photographs were taken with an Eclipse E600 microscope.

\section{Transmission Electron Microscopy (TEM)}

Small, $1 \mathrm{~mm}^{3}$ pieces of digestive gland and gills were fixed for one hour in 3\% glutaraldehyde in $0.2 \mathrm{M}$ cacodylate buffer $\mathrm{pH} 7.4$ with $1.75 \% \mathrm{NaCl}$ at room temperature. Tissues were washed three times in cacodylate buffer and post-fixed for two hours in $1 \%$ reduced $\mathrm{OsO}_{4}$ (1:1 mixture of $3 \%$ aqueous potassium ferrocyanide and $\left.2 \% \mathrm{OsO}_{4}\right)$. After washing three times with the same buffer, they were rinsed in distilled water, stained for 1 hour with $2 \%$ aqueous uranyl acetate, dehydrated in ethanol, washed in acetone, and embedded in Medcast (Pelco). Semi-thin sections, $1 \mu \mathrm{m}$ thick, were cut on a Reichert Ultracut S microtome, and stained with toluidine blue. Ninety nm thin sections were cut with a diamond knife, collected on copper grids, and stained with $2 \%$ aqueous uranyl acetate and lead citrate (Reynolds preparation: mix 1.33 g lead nitrate, 1.76 g sodium citrate and $30 \mathrm{~mL}$ distilled water for $30 \mathrm{~min}$, add $8 \mathrm{~mL}$ of $1 \mathrm{~N}$ $\mathrm{NaOH}$, and distilled water to make $50 \mathrm{~mL}, \mathrm{pH}$ 12). The sections were observed with a Zeiss EM 900 electron microscope at $50 \mathrm{kV}$, and photographs were taken.

Measurements of ten Bonamia sp. cells were taken from TEM photographs.

\section{Sex categories}

The sex categories of Chilean oysters were determined following Siddiqui \& Ahmed (2002): a) Males: follicles containing only male gonadal tissue, b) Female: follicles containing only female gonadal tissue, c) Ambisexual: follicles containing 50\% male and 50\% female gonadal tissue, d) Predominantly male: follicles containing more than 50\% male gonadal tissue, e) Predominantly female: follicles containing more than $50 \%$ female gonadal tissue, f) Indifferent: no gonadal tissue to be distinguished.

\section{Statistical analysis}

A pathogen prevalence comparison ( $X$. californiensis in red abalone, and Bonamia sp. in the Chilean oyster) was carried out among the different seasons and locations where infected abalones or oysters were detected, applying the Mann Whitney rank sum test (Canavos 1988). For analyzing if infection with Bonamia sp. was sex-related in oysters a Chi-square test for independence was applied (Canavos 1988).

\section{Results}

Two pathogens similar to OIE listed ones were detected: Rickettsiales-like organisms (RLOs) in red abalone $(H$. rufescens), and a haemocytic parasite in Chilean oyster (O. chilensis). C. gigas and H. discus hannai were free from the pathogens included in the list of notifiable diseases of the OIE.

The findings in red abalone ( $H$. rufescens) corresponded to basophilic inclusions with rickettsialeslike organisms (RLOs) observed in the post-esophagus 
(Fig. 2a,b) and digestive gland of red abalones. In severe infection cases, different degrees of metaplasia of the digestive gland epithelia were also observed (Fig. 2c).

Table 2 shows the prevalence of RLOs infection in red abalones, and the mean measurements of the 500 red abalones sampled. Eighty four abalones, with a mean size ranging from $44.0 \mathrm{~mm}( \pm 11.87)$ to $62.0 \mathrm{~mm}$ ( \pm 14.24$)$, harboured RLOs. Seventy four infected abalones had undetermined sex (immature), six were males, and four were females.
The prevalence of RLOs in summer and winter was significantly different in Dalcahue $(P<0.05)$, however, not so in Chonchi $(P=0.076)$. There were no significant differences in annual prevalence of RLOs between Dalcahue and Chonchi $(P=0.009)$.

The parasite Bonamia sp. was detected as intracellular inclusions in haemocytes, always associated to haemocytic infiltrations, especially in gills (Fig. 3a,b), and also in connective tissue around gonads, digestive gland, and mantle. Table 3 shows the prevalence for the

Table 2

Prevalence of $X$. californiensis infection and size of red abalones $\left(\mathrm{N}^{\circ}\right.$ infected/ $\mathrm{N}^{\circ}$ examined) for each zone in summer and winter

Prevalencia de infección con $X$. californiensis y talla de abalones rojos $\left(\mathrm{N}^{\circ}\right.$ infectados $/ \mathrm{N}^{\circ}$ examinados) para cada zona en verano e invierno

\begin{tabular}{lccccc}
\hline Location & $\begin{array}{c}\text { Summer } \\
\mathrm{N}^{\circ}+/ \mathrm{N}^{\circ} \\
\text { examined }\end{array}$ & $\begin{array}{c}\text { Average size }(\mathrm{mm}) \\
( \pm \mathrm{SD})\end{array}$ & $\begin{array}{c}\text { Winter } \\
\mathrm{N}^{\circ}+/ \mathrm{N}^{\circ} \\
\text { examined }\end{array}$ & $\begin{array}{c}\text { Average size }(\mathrm{mm}) \\
( \pm \mathrm{SD})\end{array}$ & Total \\
\hline Caldera & $0 / 62$ & $----/ 27( \pm 4.14)$ & $0 / 59$ & $----/ 13( \pm 1.81)$ & $0 / 121$ \\
Los Molles & $0 / 49$ & $----/ 25( \pm 6.65)$ & $0 / 60$ & $---/ 35( \pm 3.46)$ & $0 / 109$ \\
Dalcahue & $0 / 38$ & $---/ 54( \pm 21.04)$ & $18 / 50$ & $62( \pm 14.24) /$ & $18 / 88$ \\
& $(0 \%)$ & & $(36 \%)$ & $49( \pm 19.68)$ & $(20 \%)$ \\
Chonchi & $35 / 112$ & $44( \pm 11.87) /$ & $31 / 70$ & $47( \pm 7.40) /$ & $66 / 182$ \\
& $(31 \%)$ & $47( \pm 16.19)$ & $(44 \%)$ & $42( \pm 8.95)$ & $(36 \%)$ \\
Total & $35 / 261$ & & $49 / 239$ & & $84 / 500$ \\
& $(13 \%)$ & & $(21 \%)$ & & $(17 \%)$ \\
\hline
\end{tabular}

Table 3

Prevalence of Bonamia sp. and size of Ostrea chilensis $\left(\mathrm{N}^{\circ}\right.$ infected/ $\mathrm{N}^{\circ}$ examined) for each zone in summer, autumn and winter

Prevalencia de Bonamia sp. y tamaño de Ostrea chilensis ( $\mathrm{N}^{\circ}$ infectadas/ $\mathrm{N}^{\circ}$ examinadas) para cada zona en verano, otoño e invierno

\begin{tabular}{|c|c|c|c|c|c|c|c|}
\hline \multirow[b]{2}{*}{ Location } & \multirow{2}{*}{\multicolumn{2}{|c|}{$\begin{array}{cc} & \text { Summer } \\
\mathrm{N}^{\circ}+/ \mathrm{N}^{\circ} & \text { Mean size }(\mathrm{mm}) \\
\text { examined } & ( \pm \mathrm{SD})\end{array}$}} & \multicolumn{2}{|c|}{ Autumn } & \multicolumn{2}{|c|}{ Winter } & \multirow[t]{2}{*}{ Total } \\
\hline & & & $\begin{array}{l}\mathrm{N}^{\circ}+/ \mathrm{N}^{\circ} \\
\text { examined }\end{array}$ & $\begin{array}{c}\text { Mean size }(\mathrm{mm}) \\
\quad( \pm \mathrm{SD})\end{array}$ & $\begin{array}{l}\mathrm{N}^{\circ}+/ \mathrm{N}^{\circ} \\
\text { examined }\end{array}$ & $\begin{array}{c}\text { Mean size }(\mathrm{mm}) \\
( \pm \mathrm{SD})\end{array}$ & \\
\hline Calbuco & $\begin{array}{l}5 / 60 \\
(8 \%)\end{array}$ & $\begin{array}{l}59( \pm 4.83) / \\
62( \pm 6.78)\end{array}$ & $\begin{array}{l}2 / 60 \\
(3 \%)\end{array}$ & $\begin{array}{l}75( \pm 4.95) / \\
73( \pm 5.74)\end{array}$ & $\begin{array}{l}6 / 60 \\
(10 \%)\end{array}$ & $\begin{array}{l}69( \pm 3.76) / \\
69( \pm 3.46)\end{array}$ & $\begin{array}{c}13 / 180 \\
(7 \%)\end{array}$ \\
\hline Ancud & $\begin{array}{l}2 / 60 \\
(3 \%)\end{array}$ & $\begin{array}{l}58( \pm 5.66) / \\
64( \pm 5.98)\end{array}$ & $\begin{array}{l}0 / 60 \\
(0 \%)\end{array}$ & $60( \pm 11.41)$ & $\begin{array}{l}0 / 70 \\
(0 \%)\end{array}$ & $57( \pm 15.47)$ & $\begin{array}{l}2 / 190 \\
(1 \%)\end{array}$ \\
\hline Total & $\begin{array}{l}7 / 120 \\
(6 \%)\end{array}$ & & $\begin{array}{l}2 / 120 \\
(2 \%)\end{array}$ & & $\begin{array}{l}6 / 130 \\
(5 \%)\end{array}$ & & $\begin{array}{c}15 / 370 \\
(4 \%)\end{array}$ \\
\hline
\end{tabular}




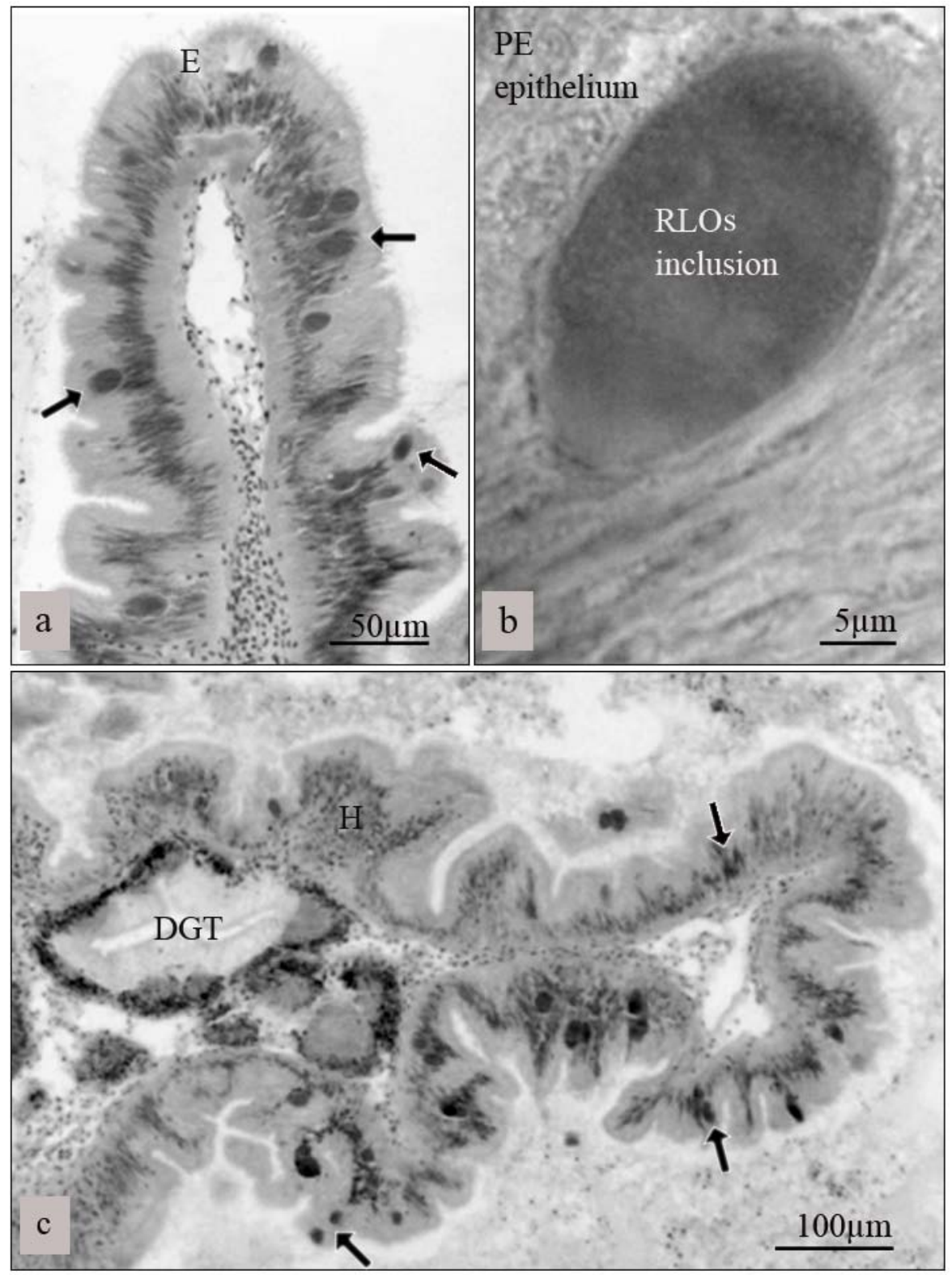

Figure 2

a) Inclusions with rickettsiales-like organisms (RLOs) (arrows) in post-esophagus (PE) epithelium (E) of red abalone. b) High power image of one inclusion with $X$. californiensis RLOs. Note the very finely granular homogenous texture of this RLOs inclusion. c) Metaplasia of digestive gland in red abalone. One digestive tubule can still be recognized (DGT). Arrows point to inclusions with RLOs (only few are labelled). H: haemocytes. Stain: H \& E

a) Inclusiones con organismos tipo rickettsiales (OTR) (flechas) en epitelio (E) de post-esófago (PE) en abalón rojo. b) Imagen de una inclusión con organismos tipo rickettsiales (OTR) de $X$. californiensis. Nótese la textura finamente granular de esta inclusión con OTRs. c) Metaplasia de glándula digestiva en abalón rojo. Hay un túbulo digestivo que aún puede ser reconocido (DGT). Las flechas apuntan a inclusiones con OTR (sólo unas pocas están marcadas). H: hemocitos. Tinción: H \& E 


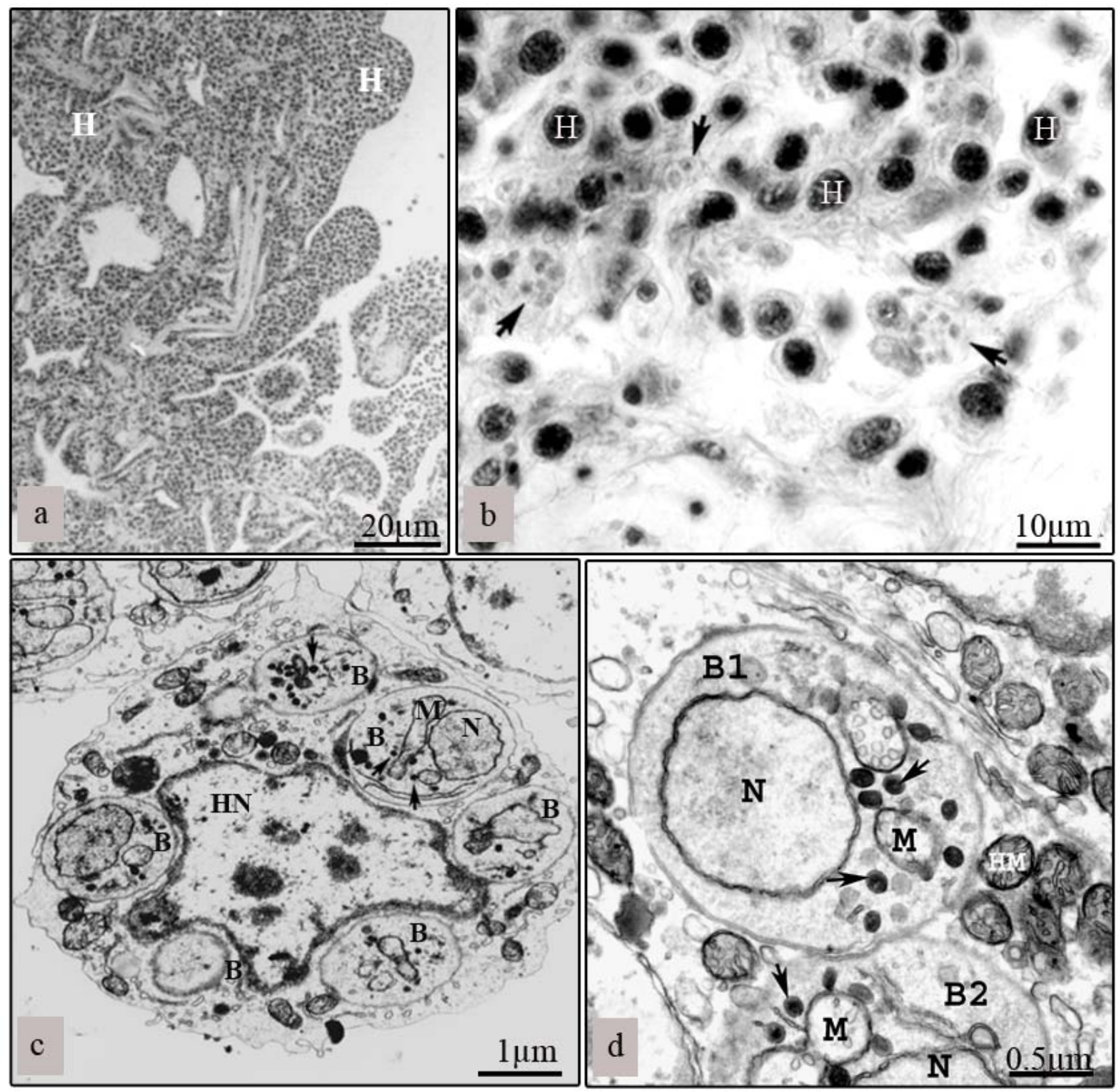

Figure 3

a) Heavy gill haemocytic infiltration in Chilean oyster infected with Bonamia sp. H: haemocytes. b) Higher magnification of Fig. 3a showing haemocytes $(\mathrm{H})$ with Bonamia sp. cells in their cytoplasm (arrows). Stain: $\mathrm{H}$ \& E. c) Transmission electron microscopy (TEM) image of one whole haemocyte with six Bonamia sp. (B) cells. HN: haemocyte nucleus; N: nucleus; M: mitochondrion. d) TEM image of Bonamia sp. cell (B1) and part of another one (B2) inside a haemocyte citoplasm. $\mathrm{N}$ : nucleus, M: mitochondrion, HM: haemocyte mitochondrion; Arrows: haplosporosomes

a) Masiva infiltración con hemocitos en branquia de ostra chilena infectada con Bonamia sp. H: hemocitos. b) Ampliación de la Fig. 3a mostrando hemocitos (H) con células de Bonamia sp. en su citoplasma (flechas). Tinción: H \& E. c) Microscopía electrónica de transmisión (MET) de un hemocito completo con seis células de Bonamia sp. (B). HN: núcleo de hemocito;

N: núcleo; M: mitocondria. d) MET de una célula de Bonamia sp. (B1) y parte de otra (B2) ubicadas en el citoplasma de un hemocito. N: núcleo; M: mitocondria; HM: mitocondria de hemocito; Flechas: haplosporosomas 
Table 4

Sex categories of all Chilean oysters sampled, and of those infected with Bonamia sp.

Categorías sexuales del total de ostras chilenas muestreadas, y de aquellas infectadas con Bonamia sp.

\begin{tabular}{|c|c|c|c|}
\hline \multirow[t]{2}{*}{ Sex category } & \multicolumn{3}{|c|}{ Bonamia presence } \\
\hline & Negative & Positive & Total \\
\hline Ambisexual & 16 & 0 & 16 \\
\hline Female & 112 & 6 & 118 \\
\hline Indifferent & 11 & 0 & 11 \\
\hline Male & 27 & 2 & 29 \\
\hline Predominantly Female & 102 & 2 & 104 \\
\hline Predominantly Male & 87 & 5 & 92 \\
\hline Total & 355 & 15 & 370 \\
\hline
\end{tabular}

three sampling periods and the two culture sites. A low power TEM image of one haemocyte with six Bonamia cells is shown in Fig. 3c. In Fig. 3d one Bonamia cell and a small section of another one can be observed. The Bonamia cells were slightly ovoid, with mean measurements of 176-147 nm (range 141-269 and 115 to $202 \mathrm{~nm}$ ). The nucleus was electron lucent, with a spherical/ovoid shape, sometimes slightly irregular (Fig. 3c,d). The haplosporosomes were spherical/ ovoid, in variable number, and often very close to the mitochondria, which had dilated cristae (Fig. 3d).

Fifteen out of 370 oysters showed infection with Bonamia sp.: 13 from Calbuco (Puerto Montt), and 2 from Ancud (Chiloé). The total of sampled oysters had an average shell length of $64 \mathrm{~mm}( \pm 10.71)$, and the infected oysters a size of $65( \pm 7.50) \mathrm{mm}$ (Table 3). The sex categories of all sampled oysters as well as the sex categories of the infected oysters are shown in Table 4.

There were no significant differences in prevalence of Bonamia sp. infections between the seasons of the year $(P=0.243)$, however, there were differences between localities, being significantly higher in Calbuco $(P=$ 0.003). The infection of Ostrea chilensis with Bonamia sp. was independent of host sex $(P=0.589)$.

\section{Discussion}

The results of this study show that molluscs cultivated in Chile are mostly free from OIE listed pathogens. The only notifiable OIE listed pathogen found was the rickettsial-like organism (RLO) Xenohaliotis californiensis that causes the foot withering syndrome in abalones. A suspected Bonamia microcell was found to be a true Bonamia, however, the correspondence to any of the two OIE listed species (B. ostreae and $B$. exitiosa) or if it is a new species is yet to be determined.

The rickettsial $X$. californiensis is an intracellular bacterium that lives in gastrointestinal epithelia of abalones, causing degeneration or metaplasia of the digestive gland. The abalones catabolize their own foot muscle proteins, which leads to atrophy of the foot, and often also to death (Gardner et al. 1995, Friedman et al. 2000). In this study the same type of basophilic intracellular inclusions described for black or for red abalone were observed, as well as metaplasia, which is characteristic of $X$. californiensis infection in red abalone (Moore \& Robbins 2000).

This pathogen was present in both sexes, and in a broad size range. It was found only in abalones from the southern zone in both summer and winter samplings. However, subsequent analysis of red abalones (20052008), showed that this pathogen is also present in the northern zone (unpublished observations). As this pathogen is disseminated in the country, it has been included in List 2 of high risk diseases in Chile, and the farmers are obliged to histologically monitor the presence of this pathogen twice a year.

The prevalence of the Bonamia-like protozoan from Chilean oysters was relatively low (up to 6\%) compared to prevalences of Bonamia exitiosa reported from the same oyster species in New Zealand (up to 51\%). The lowest prevalence was observed in April (autumn), being highest in summer and winter. Meanwhile, the infection caused by B. exitiosa in Chilean oysters from New Zealand shows peak prevalence in April (autumn) during the post spawning and egg resorption period, and a second, lower peak in August (winter). The latter is characterized by low numbers of infected haemocytes in the oyster (Hine 1991) which differs from the results of this study, where high numbers of infected haemocytes were observed.

The infection of O. chilensis with Bonamia sp. was not related to seasonality. December, January and February are peak months when larval release coincides with a period of weight loss of the oysters (Solís 1967). This situation of diminished physiological condition of the host may favor the presence of the parasite in summer. According to the same study, a second period of low oyster weight is observed in winter, which may be associated to the increased presence of the parasite in individuals analyzed in August. It may be suggested the presence of this protozoan is more related to the depressed physiological condition of the host than to reproductive or environmental factors. Similarly, the prevalence of $B$. ostrea in Ostrea edulis is not influenced by the seasonal 
temperature changes or the host reproductive cycle (Grizel et al. 1988, Montes 1991, Cáceres-Martínez et al. 1995).

The infection of $O$. chilensis with Bonamia sp. was independent of host sex as also occurs in $O$. edulis infected by B. ostreae (Culloty \& Mulcahy 1996), and in O. puelchana infected by Bonamia sp. (Kroeck et al. 2008).

This study showed the presence of the protozoa always involved a severe haemocytic infiltration in the connective tissue of the mantle, gills and digestive gland. The same inflammatory response has been described for $O$. edulis infected with B. ostreae and B. exitiosa (Balouet et al. 1983, Abollo et al. 2008), and Ostrea puelchana infected with Bonamia sp. (Kroeck \& Montes 2005).

The differences of prevalence of Bonamia sp. in both culture areas may be explained by the differences in size of the oyster farms. Calbuco in Puerto Montt (annual prevalence 13/180) is a large-scale farm and Ancud, in Chiloé (annual prevalence 2/190) is a small-scale farm. Since smaller stocks have reduced release of infective stages of Bonamia, the transmission of the parasite is more difficult (Hine 1996).

The taxonomic affiliation of Bonamia sp. in the Chilean oyster (Ostrea chilensis) is not clear. The molecular studies confirmed that it is indeed a Bonamia species (Campalans \& Campalans ${ }^{3}$ ); however, it is still not clear if it corresponds to any of the known Bonamia species or if it is a new Bonamia species (Arzul et al. $\left.2005^{4}\right)$.

The ultrastructural description of Bonamia sp. in $O$. chilensis shows that the studied parasite belongs to the Bonamia genus. It is smaller than $B$. exitiosa, the parasite of $O$. chilensis from New Zealand (NZ), being more similar to B. ostreae in size. Lohrmann et al. (2009) provided a detailed ultrastructural description of this parasite in $O$. chilensis from Chile, and compared it with other known Bonamia species. Some features, such as number of mitochondria and of lipid droplets along with the small size, are similar to $B$. ostreae. Features such as the presence of circles of smooth endoplasmic reticulum, confronting cisternae, are similar to B. exitiosa, and are only found in NZ, Chilean and Australian Bonamia. Another common characteristic of Chilean and NZ
Bonamia is an elevated number of haplosporosomes, and a well developed, nucleus apposed, Golgi body, which indicates active haplosporogenesis. Further studies, both ultrastructural and molecular, are needed to clarify if the Chilean Bonamia corresponds to any of the known Bonamia species, or is a new species.

Even though all samples from the four studied species were very carefully analyzed for the presence of any of the known OIE listed pathogens, the only true OIE listed pathogen detected in Chile was Xenohaliotis californiensis, infecting red abalone.

\section{Acknowledgments}

This research was financed by FIP grant $N^{\circ} 2003-27$. We thank Fidel Vargas from the TEM facilities of Universidad de Valparaíso for his skillful technical assistance. We are very grateful to three anonymous reviewers who improved this manuscript with their highly valuable comments.

\section{Literature cited}

Abollo E, A Ramilo, SM Casas, P Comesaña, A Cao, MJ Carballal \& A Villalba. 2008. First detection of the protozoan parasite Bonamia exitiosa (Haplosporidia) infecting flat oyster Ostrea edulis grown in European waters. Aquaculture 274: 201-2007.

Balouet G, M Poder \& A Cahour. 1983. Haemocytic parasitosis: morphology and pathology of lesions in the French flat oyster, Ostrea edulis L. Aquaculture 34: 1-14.

Cáceres-Martínez J, JAF Robledo \& A Figueras. 1995. Presence of Bonamia and its relation to age, growth rates and gonadal development of the flat oyster, Ostrea edulis, in the Ría de Vigo, Galicia (NW Spain). Aquaculture 130: 15-23.

Canavos GC. 1988. Probabilidad y estadística. Aplicación y métodos, 651 pp. McGraw Hill, México.

Campalans M, M González \& P Rojas. 1998. Neoplasia in Mytilus chilensis cultivated in Chiloé Island (Chile). Bulletin of the European Association of Fish Pathologists 18(3): 94-96.

Campalans M, P Rojas \& M González. 2000. Haemocytic parasitosis in the farmed oyster Tiostrea chilensis. Bulletin of the European Association of Fish Pathologists 20(1): 31-33.

Culloty SC \& MF Mulcahy. 1996. Season-, age-, and sexrelated variation in the prevalence of bonamiasis in flat

${ }^{3}$ Campalans J \& M Campalans. 2005. Caracterización molecular de Bonamia sp., aislado en ostras chilenas (Ostrea chilensis) procedentes de la X Región. XI Congreso Latinoamericano de Ciencias del Mar (COLACMAR), Viña del Mar, Chile. p. 240.

${ }^{4}$ Arzul I, JP Joly, M Robert, B Chollet, C García, L Miossec, N Cochennec, N Carrasco, J Campalans, M Campalans \& F Berthe. 2005. Microcells in flat oysters, Ostrea chilensis from Chiloé Island, Chile: a new Bonamia species? Journal of Shellfish Research 24: 639 [Abstract] 
oysters (Ostrea edulis L.) on the south coast of Ireland. Aquaculture 144: 53-63.

Friedman CS, KB Andree, KA Beauchamp, JD Moore, TT Robbins, JD Shields \& RP Hedrick. 2000. 'Candidatus Xenohaliotis californiensis', a newly described pathogen of abalone, Haliotis spp., along the west coast of North America. International Journal of Systematic and Evolutionary Microbiology 50: 847-855.

Gardner GR, JC Harshbarger, JL Lake, TK Sawyer, KL Price, MD Stephenson, PL Haaker \& HA Togstad. 1995. Association of prokaryotes with symptomatic appearance of withering syndrome in black abalone Haliotis cracherodii. Journal of Invertebrate Pathology 66: 111-120.

Grizel H, E Mialhe, D Chagot, V Boulo \& E Bachère. 1988. Bonamiasis: a model study of diseases in marine molluscs. American Fisheries Special Publications 18: 1-4.

Hine PM. 1991. The annual pattern of infection by Bonamia sp. in New Zealand flat oysters, Tiostrea chilensis. Aquaculture 93: 241-251.

Hine PM. 1996. The ecology of Bonamia and the decline of bivalve molluscs. New Zealand Journal of Ecology 20(1): 109-116.

Kroeck MA \& J Montes. 2005. Occurrence of the haemocyte parasite Bonamia sp. in flat oysters Ostrea puelchana farmed in San Antonio Bay (Argentina). Diseases of Aquatic Organisms 63: 231-235.

Kroeck MA, L Semenas \& EM Morsan. 2008. Epidemiological study of Bonamia sp. in the native flat oyster, Ostrea puelchana from San Matías Gulf (NW Patagonia, Argentina). Aquaculture 276: 5-13.
Lohrmann KB, AR Brand \& SW Feist. 2002. Comparison of the parasites and pathogens present in a cultivated and in a wild population of scallops (Argopecten purpuratus Lamarck, 1819) in Tongoy Bay, Chile. Journal of Shellfish Research 21(2): 557-561.

Lohrmann KB, PM Hine \& M Campalans. 2009. Ultrastructure of a Bonamia sp. in Ostrea chilensis in Chile. Diseases of Aquatic Organisms 85: 199-208.

Mix MC \& WP Breese. 1980. A cellular proliferative disorder in oysters (Ostrea chilensis) from Chiloé, Chile, South America. Journal of Invertebrate Pathology 36: 123-124.

Montes J. 1991. Lag time for the infestation of flat oyster (Ostrea edulis L.) by Bonamia ostreae in estuaries of Galicia (N.W. Spain). Aquaculture 93: 235-239.

Moore JD \& TT Robbins. 2000. Withering syndrome in farmed red abalone Haliotis rufescens: Thermal induction and association with a gastrointestinal Rickettsiales-like prokaryote. Journal of Aquatic Animal Health 12: 26-34.

Rojas P, M Campalans \& M González. 1999. Hemocytic neoplasia in the Chilean oyster (Tiostrea chilensis) cultured in the south of Chile. New record. Investigaciones Marinas, (Chile) 27: 15-18.

Shaw BL \& HI Battle. 1957. The gross microscopic anatomy of the digestive tract of the oyster Crassostrea virginica (Gmelin). Canadian Journal of Zoology 35: 325-347.

Siddiqui G \& M Ahmed. 2002. Gametogenic patterns of the larviparous oyster Ostrea nomades from Karachi, Pakistan (Northern Arabian Sea). Aquaculture Research 33: 10491058.

Solís IF. 1967. Observaciones biológicas en ostras (Ostrea chilensis) de Pullinque. Biología Pesquera 2: 51-82. 